\title{
Design education learning: developing skills of observing and managing intangible systems in young generations
}

\author{
Bergamini, Isabella $^{a}$ \& Fanzini, Daniele ${ }^{b}$ \\ ${ }^{a}$ Facultad de Ingeniería, Universidad Panamericana Campus Guadalajara, Mexico. ibergamini@up.edu.mx; \\ ${ }^{\mathrm{b}}$ Dipartimento ABC, Politecnico di Milano, Italy. daniele.fanzini@polimi.it.
}

\begin{abstract}
There is consensus among researchers regarding how managing and designing in complexity multidimensionality represents one of the mains challenges and constants of contemporaries' processes of innovation (Manzini, Baule, Bertola, 2004). This systemic distinguishing peculiarity makes impossible to standardize the design innovation processes because every problem needs to be solved by adopting different strategies (Celaschi, Deserti, 2007). Nevertheless, those innovative processes can be developed and managed by referring us to tools and practices of design into the paradigms of multidisciplinary and multidimensional.
\end{abstract}

However, what happens when professors have to transmit those concepts to young students of design faculties? We have to consider that normally those students are coming from second-degree schools, which programs usually still insist on content rigidly divided in disciplines and don't consider how the contemporary relation between space and time has overturned for them (Morin, 2001). Young students generally disclaim their past in the meaning of heritage, values and techniques knowledge; they live in the present, a time that does not exist; a time that today results enormously expanded by globalization processes. They still living in a reality of which territorial capital subsystems are characterized by an entropic strong dichotomy of entities in opposition but, on the other hand, in balance within themselves, as for example topics as material/immaterial, collective/identity, culture/industry, etc. So, which are the design didactic challenges to provide horizontal skills for allowing young students to understand complexity and manage knowledge of the reality?

This article will discuss the case study of the perception among design of a newly generation admitted at the Innovation and Design Engineering Degree of the Universidad Panamericana - Guadalajara Campus. As expected, in this new generation we can especially observe a resistance to consider the sociocultural, business, technological and territorial dimensions as systems that strategically characterized and affected plural aspects of the design innovation processes. The contribute then proceed in analyzing case studies of didactic activities for creating skills and sensibility able to develop this capability to observe, select and manage the intangible in order to optimize the design of the tangible in the young generations. 
The investigation, through the experimentation and comparison of informal didactic model, bring to the identification and promotion of special extra-ordinary didactics experiences oriented to the complex project and able to resalt the designer mediation role among the innate and dualistic tension between polarities able to resalt the intangible aspects which characterized contemporary design processes.

Keywords: design education, management of intangible, young generations, learning process, Universidad Panamericana.

\section{Introduction}

"Se dice cada vez más a menudo "eso es complejo" para evitar de explicar. Es necesario proponer una verdadera ruptura y poner de manifiesto que la complejidad es un reto que el espiritu debe y puede conquistar» (Morin, Ciurana, Motta, 2003).

There is multidisciplinar consensus among the need to rethink the profile of futures designer professionals by growing their capabilities of managing and solving complex problems. This need arises from the (pos)posmodern demand of heighten the number of factors, indicators and variables to take into account in advanced design process focused to anticipate futures and to bring man at the center of the project by contempling primary factors that modern societies didn't considere as environmental, cultural and social issues, etc. (Celaschi, 2000). The analysis of best practices of professional advance design works, underlines several common factors: «the barriers between various fields (research, academia, business, environment, public administration, population) were cancelled thus opening new transfer and sharing channels, enable the knowledge exchange. The design of various relationship took a determinant role [...]» (Fanzini et al., 2014).

One of the most prominent voices who have faced this issue from the educational point of view is the anthropologist, became philosopher, Edgar Morin. As father of complex thinking paradigm, Morin suggests a dualistic approach to integrate the «analytic vocation of positivist sciences with the transdisciplinary and problematizing vocation of substantive philosophy» (Romero-Pérez, 2003, p.2 ). In his "Seven complex lessons in education for the future" (Morin, 2001), the author explains crucial problems which are needed to teach in the schools of every country. Among these, we should highlight the "Principles of pertinent knowledge" which statement is to encourage, through innovative education methods, the innate human propension to insert partial and circumscribed knowledges of different disciplinar areas in relation within thems and with the whole. Morin suggests to move on from old traditional education models for enabling in students the ability to restore relations and reciprocal influences betweens parts and total, where total is referring to the context, the global, the multidimensional and the complex; as well as strengthen the aptitude to set and solve essencial problems (i.e. general intelligence). Rebuild relationships between the parts and the whole means to overcame reduction and disjunction between humanistic and hiper-specialized science discipline and to finally take into account intangible and no measurable elements which were tradicionally eliminated during the phase of simplification of a problem (reductionism). 
The urgence to form in young generations the ability of managing and solving complex problems is also expressed by the World Economic Forum as the most important of the ten skills professional need to thrive in the Fourth Industrial Revolution (Gray, 2016) .

The statement we are discussing is also well explored and expressed by Pier Giuseppe Rossi in his book "Tecnologia e costruzione di mondi: post-costruttivismo, linguaggi e ambienti" (Rossi, 2010). Rossi underlines how the paradigm change from linear to complex scientific approach requires to transcend the disciplinar division of Western cultures and to design finally new pervasive technologies for education process. The author stresses the need to leave linear and reductionist approaches in favor of complex, ecosystemic and enactive ones. Rossi recognize that contemporary cognitive processes are oriented to wordls construction and knowledge production rather than acquisition of informations. The changing paradigm also impact into researches, which move on from a model hipotesys - experiment - test, to a model design - action - thought.

This premise leads us to interrogate among various statements. If young generations are coming from second-degree schools, which programs usually still insist on content rigidly divided in disciplines and don't consider how the contemporary relation between space and time has overturned for them, how professors of design faculties can manage the learning process for fostering and developing in them the skill of observing, synthetizing and managing complex systems? Is it possible to identificate best practice which helps professor to fostering student's skills of detecting and working on the intangible factors which affect a complex system?

\section{Methodology}

The article is conceives by referring to metadesign methodology in the disciplinar frame of Advanced Design Cultures, which process refers to differentes phases.

First, we observed reality by inquirying three group of the newly generation admitted at the Innovation and Design Engineering Degree of the Universidad Panamericana - Campus Guadalajara (Mx) about their percepcion among design definition to identify cultural constants in their thoughts.

Second, we conduced a multidisciplinary literature analysis which led us to isolate some fundamental principles. This activity allowed defining the complex project approach as centre of the (design) education debate. On the basis of this investigacion a learning experience was designedand experimented within the students of the Politecnico di Milano (Italy) and the Universidad Panamericana - campus Guadalajara (Mexico).

Third, we recollected and analyzed several high significative education activities realized in a selection of Latin American Design Faculties or countries which permit to experience managing solving complex problem skills.

\subsection{The perception of design in newly generation admitted at the Innovation and Design Engineering Degree of the Universidad Panamericana - Campus Guadalajara (Mx)}

In August 2015 we conduced a capillary enquest which aim was to investigate the percepcion about design in newly generation admitted at the Innovation and Design Engineering Degree of the Universidad Panamericana - Campus Guadalajara (Mx). Before starting the didactic activity of "Design"Principle" course, it was asking to the sixty young students crossing that discipline, to define the therme "Design" in a short text. Moreover, those definition were elaborated to extrapolate keywords with the aim to facilitate a comparison between the concepts expressed. 


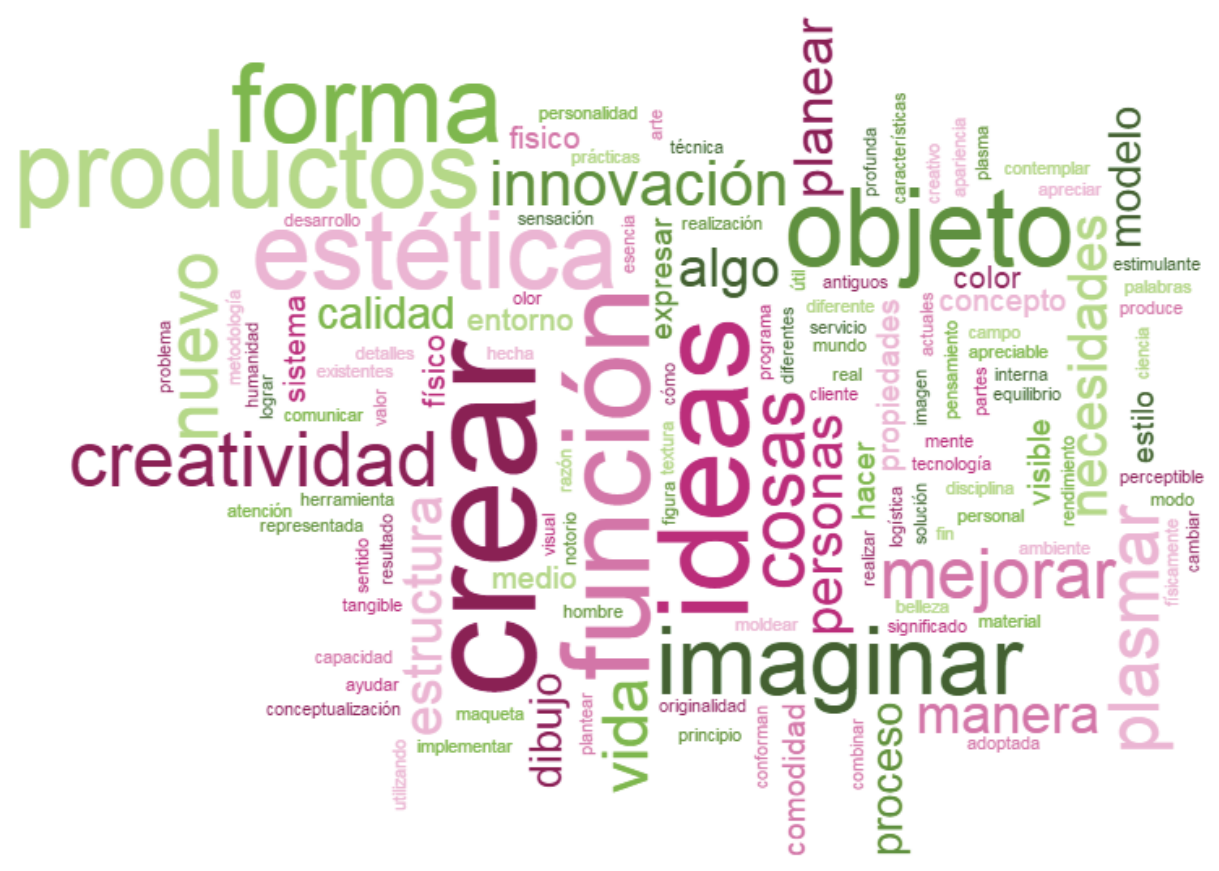

Fig. 1 Word cloud that synthetize the definition of design provided by the students of the course "design Principle" of the Innovation and Design Engineering Degree of the Universidad Panamericana - Campus Guadalajara (Mx) in August 2015.

Has we can observe in the Figure 1 - where the dimension of every word depends on the number of repetitions of each relative to the total of the definitions - the percepcion of this statistic sample about the meaning of design lacks of numerous important concepts comparing to the design definition purposed by Flaviano Celaschi (Germak et al., 2008): «[design is] the way in which, in the contemporary system of trade, results are achieved in the form of products, services and experience, in which the significance, value, form and function are integrated and bring about universally recognised effects that lead to the exchange of these commodities on the market». The focus of the meaning of design expressed by young students, despite their digital nativity, is clearly oriented to a culture of tangible product rather than a culture of proyect (also oriented to achieve services and experiences results), where function and form are the main statement to balance with creativity for resolving a problem and where there is no perception about context or operational assessment (market, industry, technology,...) and contemporary intangible aspects as meanings, values, processes, time, culture, multidisciplinarity, and so on.

The collective definition of design suggested by students obviously find a connection with the design perception of non-experts, as they are when entering to a design school. Nonetheless we should identifying at least two factors, local and global, that should had an impact in their definitions. First, they are living in a country that, as the majority of Latin American nations, has a strong original arts and crafts tradition, rather than industrial one, as USA or Germany for example, have. This consideration, joined with the analysis of literature about Mexican design school evolution, shows how Design «has experienced slower development by local circumstances where, for historical reasons, innovation for the creation of goods and production has been marginalized for political reasons, and the national market subject to a culture based on the copy or inspiration in ways of life foreign to ours» (Flores, 2010). Second, exactly as it happens to students of all other the world, young designers are coming from seconddegree schools, which programs usually still insist on content rigidly divided in disciplines which are not 
considering how the contemporary relation between space and time has overturned for them (Morin, 2001).

So, which are the design didactic challenges to provide horizontal skills for allowing young students to understand complexity and manage knowledge of the reality?

\subsection{Highlits from the current debate on design education innovation}

Due to the evolution from industrialized to knowledge based society, advanced industrialized companies have developed counciousness nearby informations and operative judgment are becoming necessary to produce innovation. Univeristies are stilling evolving in this contexts, trying to anticipate future needs of our societies by investing intellectual and economic resources for growing knowledge and disseminating it by training.

The focus that this article would to attempt, lead us concentrating on this second statement, i.e. on the dissemination of knowledge in the practice of design education as a priority. As the chapter "Research for design education: some topics" of the book "Innovation in design education" (Formia, 2012) well highlighted, we can identify from literature and case studies, some strategic and correlated themes at the centre of design education research debate. According to the author Antonella Penati, the theory/practice relationship should be identified as the core of design reflections and has generated several studies and approaches with the aim of integrating boths aspects for developing what Jane Abercrombie (Abercrombie, Patella, Giordano, 2003) has defined as “operational judgment”. Penati's contribution facilitates the individuation of dydatic approaches that we identified in the diagram shows below.

\section{Instrumental and operational skills}

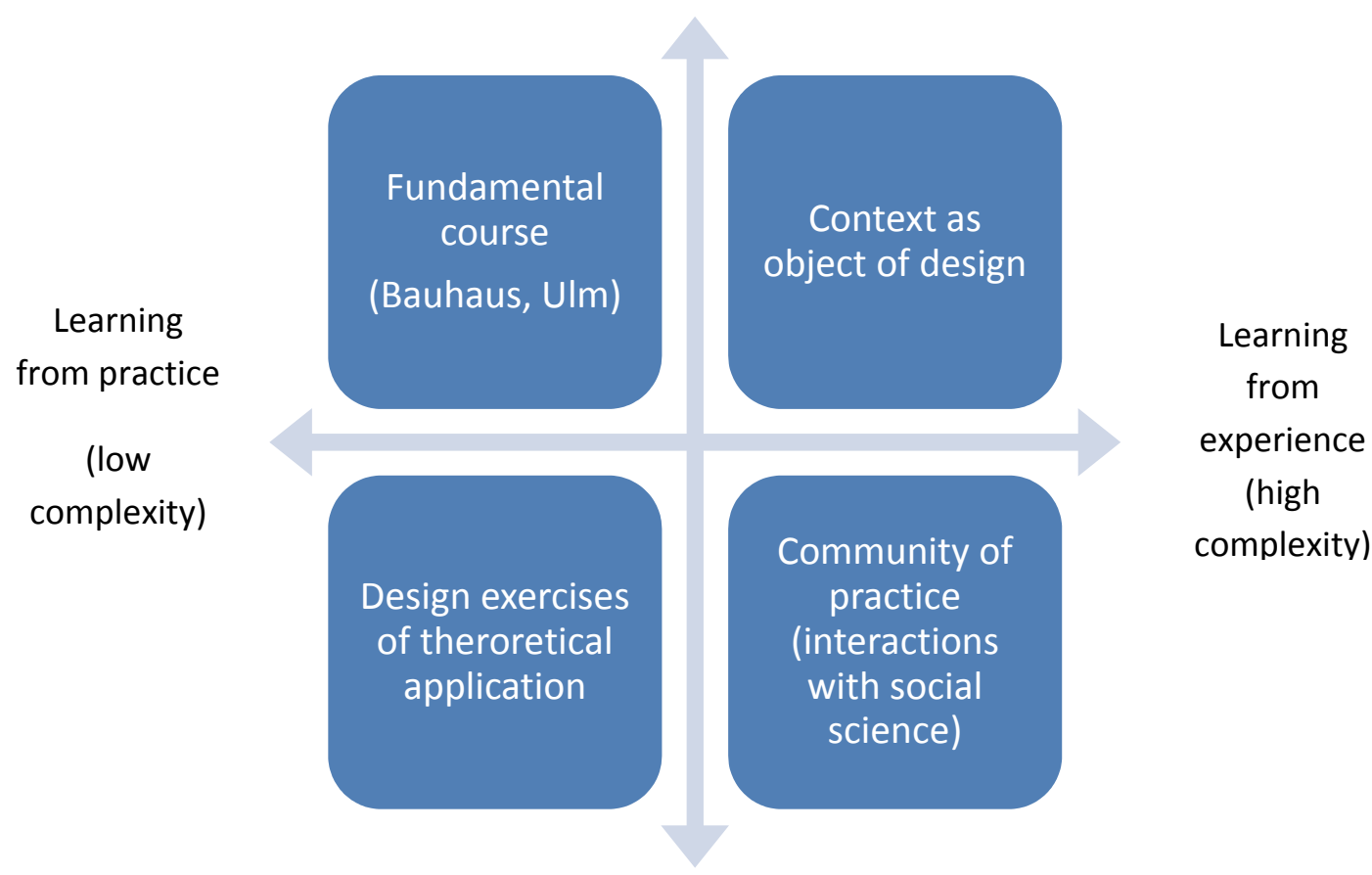

Theoretical knowledge

Fig. 2 Dydactic approaches of design education 
The scheme objective, despite its simplicity, is to emphasize how recent debate among didactics education seems move from the learning with practice approach to the learning with experience approach, answering to the contemporary need of increasing complex problem solving student's capabilities by introducing activities able to develop skills as analysis of context and by transforming it in object of design. The main challenges in design education that literature is purposing refers therefore to two primary issues answering to the statement of knowledge as basis of good design recognized by Flaviano Celaschi (Germak et al., 2008, pp. 29-30) which are: «have very good knowledge of the phenomenon on which one is working in order to find the innermost essence of the problem that is to be solved; use a language of synthesis of the phenomenon that is capable of preserving the essence of the problem».

The postulation of metadesign process as apparatus of design practice innovation, provides us a frame of tools and methods which enormously improve the phase of a design process: the knowledge of the phenomenon by stimulating the literary sources and context investigation, also in disciplinar field and areas which are not stricty related to the problem analyzed (Celaschi, Deserti, 2007).

Referring to the visual thought, as underlined by Antonella Penati, the italian design research literature identified two main areas of interest: on the one hand, the research line concerning the product identity communication which is going further the visualization of tangible qualities for including in the construction of scenarios all intangible qualities related to communication, emocions and senses; on the other hand, the research line concerning the design of scenarios of possible futures (intangible) which is explored by innovative design processes which requiring the designer talent of implementing «new values, behaviours, methods of use, functional solucion and possibilities of services» (Formia, 2012, pp.64-65).

\subsubsection{Pedagogic issues in the complex paradigm}

The pedagosist literature is plenty of authors who analyze the epistemological principles that sustain the paradigm of complexity for detecting new theroretic and methodologic models which should aid the scientific community to elaborate theories more fitted to the reality. Due to the nature of complexity, it seems quite impracticable, from the scientific point of view, to define exact methodological recepies that precisely defines the path to take for teaching in the systemic paradigm. Robinson Roa Acosta, in his dissertation on "Formación de profesores en el paradigma de la complejidad" (Roa Acosta, 2006), rather than remember that professors should be themselves educated in the complex paradigm for well developing their educative missions, indirectly suggests guideline helpful to understand primary elements to take into account for correctly design systemic educational methodologies. Between them we highlight:

- develop a vision and a shared mission with students;

- $\quad$ propender for the development of academic activities, establishing the largest possible number of relationships with other fields of knowledge;

- $\quad$ select, organize and structure resilient academic curricula that promote learning related to reality;

- develop laboratory practices through problem solving that allow, in unison with the theory, the appropriation of contextualized conceptual elements:

- $\quad$ students do face real problems of disciplinary and interdisciplinary work;

- seek the participation of students in the formulation, development and management of research and knowledge from and between different fields of knowledge; 
- allow colleagues and students to make decisions regarding the educational activities of a class (participacion logic);

- plan an evaluation system of activities to assess the impact of the class and help improve them.

\subsubsection{What do we expect from a design training model?}

The design literature is rich of recent dissertations regarding design training models and pedagogical aspect. So the objective of this part of contribution, more than wanting to be exhaustive, it's to resume the main aspects to take into account for understanding the complexity of design a Design career.

First, it is strategic to define the profile of the designer that we want to educate for the future. According with the concepts previously expressed, Claudio Germak (Germak, Bozzola, 2010; Germak et al., 2008) traces an anatomy of the professional profiles of designers, which he calls "exploring designers", in relation to the exploration activities that a project requires. Based on twenty years of experience of the Politecnico di Torino (Italy), the author identifies three alternative/evolutionary/complementary professional profiles:

1. The conscious designer. His/her products have cultural value and are based on the purpose and accuracy of the performance provided.

2. The scenario designer. He/She works in collective research connected with other areas of specialization to produce scenarios in which «contextual values are accumulated to form critical mass: social, cultyral, ethical, biological and technological values»

3. The navigating designer. Proactive figure with inexhaustible curiosity in search of new territories of project. He/She is an innovator because is able to go further the common sense and has developed a wide range of multi/interdisciplinary, sociocultural and material references.

According with various schoolars (Penati, 2015; Maldonado, 1974), design process of learning consists of a broad variety of methods which are on complementarities but at the same time in opposition each other, as sohwn in the image below. 


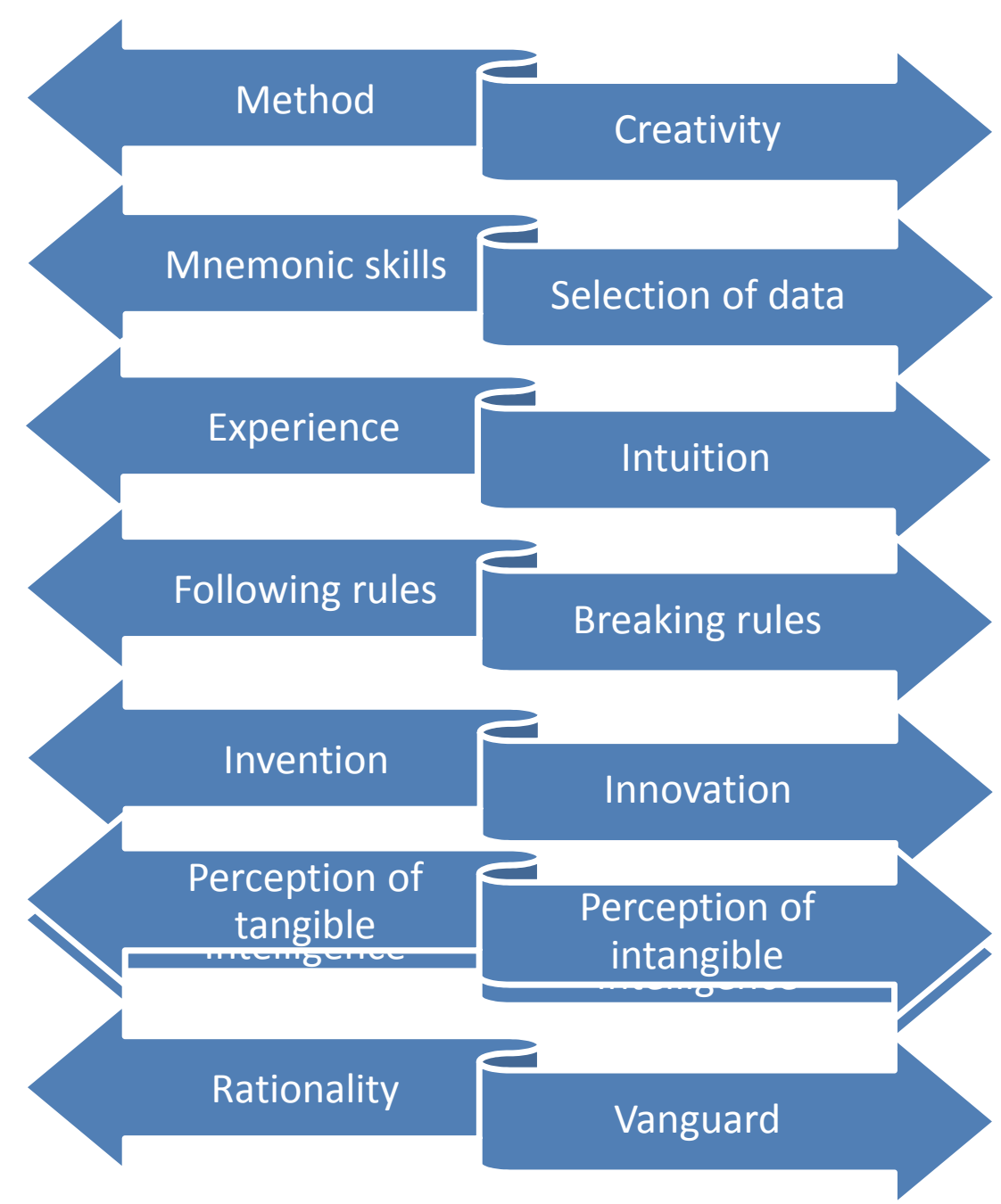

Fig. 3 Antithetic/Dialectic relationship between strategic designer skills

The tension between dualistic forces in balance is the core of design process. The antinomy and complementariety between concepts, rules and methods should be indentified as extreme consequence of complex thinking paradigm (Morin, Ciurana, Motta, 2003). Depending on how much the educators/designers stress those forces and are able to make more strong the curiosity of student, they should get different professional profiles. With how much educators want to achieve an innovator designer profile, how much the strategic designer skills showed above have to coexist in the same individual.

Also due to the progressive dematerialization of products, the need to form in young student the capabilities of analyzing and managing intangible factors of a system, as one of strategic designer skills to achieve innovation, is growing. According with several authors (Germak et al., 2008; Penati, 2015; García-Garrido, 2015; Papanek, 1977), it remains primary to include a set of humanistic discipline into design school curricula. 


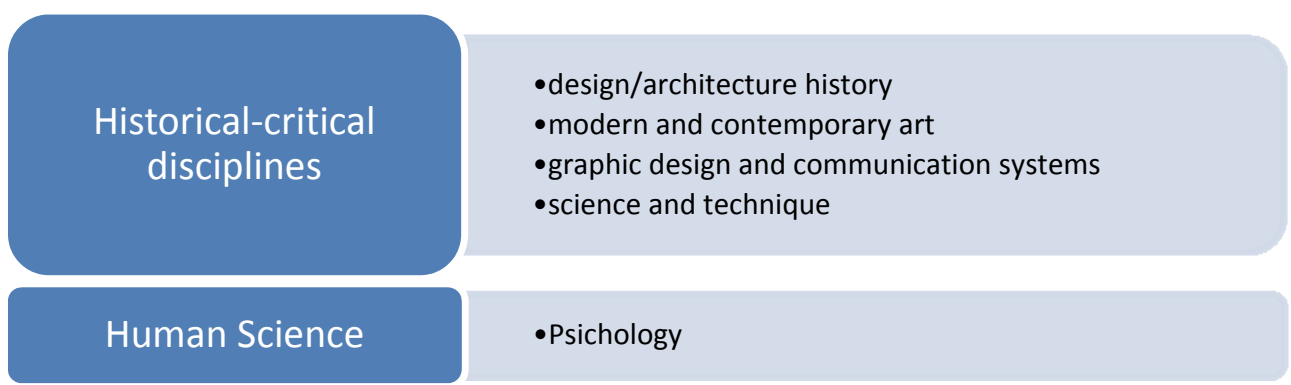

\section{Ergonomic Disciplines}

\section{Theories of languages and signing systems \\ -philosophy of language - semiotics -theory and sociology of communication}

Social and cultural

anthropology and

ethnographic studies

\section{Economics and social disciplines}

Fig. 4 Humanistic Discipline contributing to a Pedagogy of design. Fuente: (Penati 2015, pp.77-79)

\subsection{Intangible context factors}

Scholars are recently starting to explore the strategic potential of Design to imagine and communicate tactic and scenarios for the change, by operating with agent activators that work on a territory (Celaschi, Germak, 2009). Approaching the context from the point of view of a design project means to understand the evolving tangible and intangible parts of which it is composed as well as the relationships between themselves.

One of the most interesting contemporary approach analizing the local context is recognized in the researches on the territorial capital lead by Roberto Camagni (Camagni, 1999). Camagni's assessment were been officialy included in the regional development EU politcs of the Organisation for Economic Co-operation and Development (OECD), with the report Territorial Outlook 2001. The report demonstrates that every region have its own specific territorial capital which is able to make certain types of investments more effective compared to others. The factors that play a key role in the territorial capital definition are geographic location, size of the region, climate, natural resources, quality of life and economies of scale. To these other factors affecting the traditions or local and regional costumes are added, as well as, the quality of governance, which includes issues such as mutual trust and informal rules that enable different actors to work together under conditions of uncertainty according to principles of solidarity and mutual assistance (social capital). Lastly, into the territorial capital are coming into play immaterial factors defined by the OECD report as "something in the air or environment", arising from the interaction of institutions, rules, practices, producers, researchers and policy makers that facilitate the conditions for the development of creativity and innovation, namely what is defined as "quality of the milieu" (Zonneveld, Waterhout, 2005).

According to the definition proposed by the OECD, Francesco Zurlo summarizes the territorial capital as «the combination of physical and intangible elements available to the area that can be strengths or real 
constraints, depending on the aspects taken into account» (Zurlo, 2003). The Zurlo's concept of territorial capital implicates all the integrated elements that form regional prosperity:

- Know-how, which is the set of knowledge and skills necessary to perform certain work, research and development activities;

- Human resources;

- Physical resources, which is the set of natural objects, cultural and infrastructure;

- Forms of governance;

- Markets and relations with the exterior.

A more detailed taxonomy of the assets that characterized the innovation processes of territorial capital has been more recently published by Roberto Camagni (Camagni, 2008)

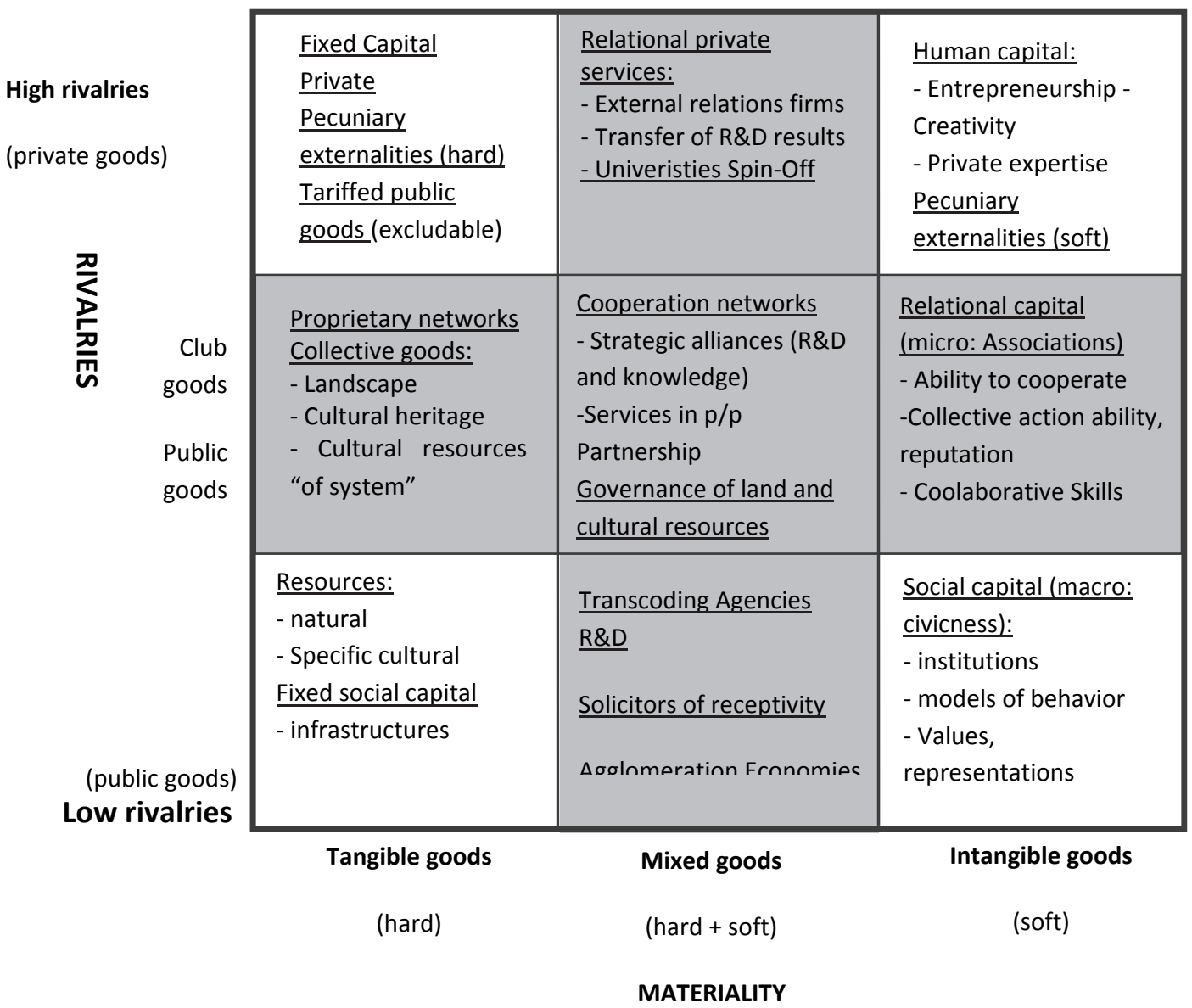

Fig. 5 Classification of territorial capital as a function of materiality issues and rivalries Source: Camagni (2008)

The elements that Camagni considers are divided according to their materiality. At the corners of the matrix (resources, social capital, human capital, private capital) there are the simplest elements to be determined, i.e. those which normally come in themselves working for a traditional land transformation process. The elements placed in the gray fields are otherwise characterized by more diaphragmatic limits and more complex definitions. They are formed by intermediate classes of goods that require strong 
elements of relationship with the other elements of the territorial context and that can assume strategic roles in the governance of local development processes. They usually result from complex cognitive processes that have taken place over time on a territory, generating in the local community the ability to learn from the experiences conducted. In the center of "innovative cross" the author recognizes the strategic importance of alliances for Research \& Development (R\&D) and for the creation of knowledge, supported by transcoding agencies, those that designers define mediators. Camagni's definition of territorial capital offer a wide and exhaustive panorama about the systemic nature of a local context.

The contents of the intangible column: human, relational and social capital bring us back to those humanistic statements which were mentioning above, while in relations with other paradigmatic elements of a place. A human centered focus of design practice, as cultural act, should not separate the man from the context during the phases of a design process.

Referring the territorial capital concept to the Design concepts expressed by Flaviano Celaschi we could thereforme affirme that context is a strategic and irreplaceable factor that contain elements which guide designer in shaping products, experiences and services (Celaschi, Germak, 2009).

\subsection{Learning from a real context}

In the practice of design educations, students are called to develop a wide selection of activities. In this part of the contribution we want to identify tipologies of design education activities which are experimenting the growth of complex thoutgh abilities in student which are coursing project centered academic career. This analysis does not pretend to be exhaustive, but suggests the possibility of enhancing the international relations created starting from the Latin American of Design network to share information on teaching practices that provide the development of skills within the complex thought, as well as on extraordinary activities that allow students to go beyond the "limits" of the Academia for coming into direct contact with the real context and/or professionals of different disciplines and experiences.

A first cathegory of this kind of activities it's usually realized from professor trained to the complex thought who use building and/or cultural/social context as design' object. It's the case of the majority of doctoral workshop held by the ABC Department of Politecnico di Milano (ITA) ${ }^{15}$, or as, for example the design courses led at the Faculties og Innovation and Design Engeneering of the Universidad Panamericana campus Guadalajara $(\mathrm{MX})^{16}$. The list were be very large.

A second cathegory of experiences could be related to the fact that in the contemporary university contexts all other the world is quite commun to find a system of validation of student performances by recognizing formative credits. This means that exist facilities that allow students to undertake, with greater simplicity, national and international interchange programs in other Universities or participate in extra-curricular educational activities of various kinds. This opening led us to detect other kind of extracurricular experiences which undoubtedly could have a stronger impact in the professional growth of design students. We are referring to a wide variety of temporary events as workshops, summer schools, design driven incubators that are managing with multi and infradisciplinarity, multiculturalism as well as, the dualistic soul of our contemporaneity, i.e. local and global. Those kind of activities also help students

\footnotetext{
${ }^{15}$ Cultural Heritage conservation and Valorization Workshop: students were called to design projects for the relaunch of cultural district of Oltrepo Mantovano Region (Italy) as concluding act of a participated project process which involved local institutions and culturale stakeholders. The output of the process were adopted by the cultural district governance for the search of new public and private funding.

${ }^{16}$ Taller de innovación y diseño estetico: metadesign practice for the regeneration of the Zapopan Centre, Historique Centre department of Zapopan governemt involved; Taller de innovación y diseño ergonomico,- Development of products for improving the life quality of children with disabilities, Hospital CRIT Teleton Guadalajara involved.
} 
on one hand to understand the uncertainity of reference context and social/cultural/economic players and on the other hand to detect the main global innovation corridors. In the table below we are schematically illustrating few impacting best practice to which we are referring.

Tabla 1. Extracurricular activities case studies

\begin{tabular}{|c|c|c|c|c|}
\hline $\begin{array}{l}\text { Experience } \\
\text { tipologies }\end{array}$ & Reference & $\begin{array}{l}\text { Reality } \\
\text { investigated }\end{array}$ & Subjects & Characteristics \\
\hline $\begin{array}{l}\text { Extracurricular } \\
\text { activities } \\
\text { promoted by } \\
\text { University }\end{array}$ & $\begin{array}{l}\text { Design now } \\
\text { summer school }\end{array}$ & $\begin{array}{l}\text { Milan future fab } \\
\text { city }\end{array}$ & $\begin{array}{l}\text { Bachelor and } \\
\text { master students of } \\
\text { various faculties }\end{array}$ & $\begin{array}{l}\text { Context as design } \\
\text { object, } \\
\text { Anticipation, } \\
\text { infradisciplinarity }\end{array}$ \\
\hline $\begin{array}{l}\text { Extracurricular } \\
\text { activities } \\
\text { promoted by } \\
\text { University }\end{array}$ & $\begin{array}{l}\text { ROMA 20-25 } \\
\text { Nuovi cicli di vita } \\
\text { della metropoli, } \\
\text { workshop and } \\
\text { exposition }\end{array}$ & $\begin{array}{l}\text { Envisioning the } \\
\text { future of Rome }\end{array}$ & $\begin{array}{l}\text { National and } \\
\text { International } \\
\text { Universities }\end{array}$ & $\begin{array}{l}\text { Context as design } \\
\text { object, } \\
\text { Anticipation, } \\
\text { infradisciplinarity } \\
\text { multiculturality }\end{array}$ \\
\hline $\begin{array}{l}\text { Extracurricular } \\
\text { activities } \\
\text { promoted by } \\
\text { firms }\end{array}$ & $\begin{array}{l}\text { Innovation } \\
\text { Workshop de } \\
\text { Continental }\end{array}$ & Future vehicles & $\begin{array}{l}\text { Students of } \\
\text { various faculties }\end{array}$ & $\begin{array}{l}\text { Anticipation, } \\
\text { infradisciplinarity }\end{array}$ \\
\hline $\begin{array}{l}\text { Extracurricular } \\
\text { activities } \\
\text { promoted by } \\
\text { universities and } \\
\text { Association }\end{array}$ & $\begin{array}{l}\text { Future ways of } \\
\text { living } \\
\text { Charrette - }\end{array}$ & $\begin{array}{l}\text { How technologies } \\
\text { will impact future } \\
\text { ways of living }\end{array}$ & $\begin{array}{l}\text { Institute without } \\
\text { Boundaries (CA), } \\
\text { Meet the Media } \\
\text { Guru (ITA), } \\
\text { students } \\
\text { professional, } \\
\text { scholars }\end{array}$ & $\begin{array}{l}\text { Anticipation, } \\
\text { infradisciplinarit, } \\
\text { multiculturality }\end{array}$ \\
\hline $\begin{array}{l}\text { Extracurricular } \\
\text { activities } \\
\text { promoted by } \\
\text { informal networks }\end{array}$ & $\begin{array}{l}\text { Global Service } \\
\text { JAM - } \\
\text { internacional } \\
\text { streaming } \\
\text { workshop }\end{array}$ & Design services & $\begin{array}{l}\text { Universities, } \\
\text { scholar, students, } \\
\text { profesionals, } \\
\text { citizen... }\end{array}$ & $\begin{array}{l}\text { Multiculturality, } \\
\text { infradisciplinarity }\end{array}$ \\
\hline
\end{tabular}

\section{Conclusion}

Sociological, pedagogist and design scientific scholars recognize the strategic urgent need to find ways for cultivating and enhancing in young generations the skill of managing and solving complex problem with the hope of forming professionals able to find more economic/social/ambiental sustainable and ethic solutions to problems. Despite the investigations, the same nature of complex thinking inhibits investigators to achieve exact recipes for resolving the pedagogical need of developing educacional methods able to strengthen in young generations the systemic thought.

From the point of view of design education, the model of metadesign process should answer, from the didactic and professional point of view, to the exigence of guiding designer into the project complexity by stressing and dilating the phase of investigation which anticipates the same design phase. Design discipline also is moving from the learning with practice approach to a learning with experience approach. This means that the activities that more develop into students the capacity of dealing with high complexity are recognizable in two main achieve: working with the context as object of design and working immersed into communities of practice. Undoubtely both events should accelerate the process of 
student immersion into reality, the experimentation of what means intangible and develop the innate curiosity to understand the parts in relation with the whole.

Despite the lack of tools for verifying the rise of complex thinking into young design generations, which suggest new routes for multidisciplinary investigation, it seems obvious to recognize, especially in the extracurricular activities led by universities, with the partnership of firms and/or formal/informal external organizations (or viceversa), an excellent start point to mature multidisciplinary, multicultural, advanced and intangible factors sensibility.

\section{References}

ABERCROMBIE, M.L.J., PATELlA, A., GIORDANO, M. (2003). Anatomia del giudizio operativo. Milano: Franco Angeli.

CAMAGNI, R. (1999). "The city as a milieu: applying Gremy approach to urban evolution" in Revue d'Economie Régionale et Urbaine, vol. 3, pp. 591-606.

CAMAGNI, R. (2008). "Regional Competitiveness: Towards a Concept of Territorial Capital" en: Capello, R., Camagni, R., Chizzolini, B., Fratesi, U. Modelling Regional Scenarios for the Enlarged Europe. Verlag Berlin Heidelberg: Springer, pp. 33-47. ISBN 978-3-540-74736-9.

CELASCHI, F. (2000). Il design della forma merce: valori, bisogni e merceologia contemporanea. Milano: Il Sole 24 Ore.

CELASCHI, F., DESERTI, A., (2007). Design e innovazione. Strumenti e pratiche per la ricerca applicata. Roma: Carocci.

CELASCHI, F., GERMAK, C. (2009). "Design e territorio: due scale di progetto sinergiche" en: Campagnaro, C., Lupo, E. Designing Connected Places: International Summer School. Bologna: Compositori, pp. 9-11.

FANZINI, D., CASONI, G., BERGAMINI, I. et al. (2014). "Advance Design for Territorial Innovation and Development". Celaschi, F., Iñiguez Flores, R., León Moran, R. M. et al., 5th International Forum of Design as a Process. The shape of the future as the front end of design driven innovation. Guadalajara: Tecnológico de Monterrey. 157-165.

FLORES, O.S. (2010). "La cultura de la evaluación y la historia del diseño en América Latina" en Revista Cultura de Guatemala, vol. 31, no. 2, p. 187-197.

FORMIA, E. M. (2012). Innovation in design education. Theory, research and processes to and from a Latin perspective. Torino: Umberto Allemandi \& C .

GARCÍA-GARRIDO, S. (2015). Diseñar para una era humanista: Innovación transversal entre Arte, Diseño y Artesanado. Madrid: Editorial IED.

GERMAK, C., BOZZOLA, M. (2010). "The exploring designer: a design training model in Italy" en Strategic Design Research Journal, vol. 3, no. 1, p. 13-19.

GERMAK, C., CELASCHI, F., BISTAGNINO, L. et al. (2008). Uomo al centro del progetto, design per un nuovo umanesimo. Man at the centre of the project, Design for a new humanism. Torino: Umberto Allemandi \& C.

GRAY, A., (2016). The 10 skills you need to thrive in the Fourth Industrial Revolution. < https://www.weforum.org/agenda/2016/01/the-10-skills-you-need-to-thrive-in-the-fourth-industrial-revolution/> [Consulta: 22 de abril de 2016]

MALDONADO, T. (1974). Avanguardie e razionalitá. Torino: Einaudi.

MANZINI, E., BAULE, G., BERTOLA, P. (2004). Design multiverso: appunti di fenomenologia del design. Milano: Poli.design.

MORIN, E. (2001). Seven Complex Lessons in Education for the Future: Education on the Move. Genebra: UNESCO Publishing.

MORIN, E., CIURANA, E. R., MOTTA, R.D. (2003). Éduquer pour l'ère planétaire: la pensée complexe comme méthode d'aprentissage dans l'erreur et l'incertitude humaines. Paris: Balland.

PAPANEK, V. (1977). Diseñar para el mundo real: ecología humana y cambio social. Madrid: Hermann Blume. 
PENATI, A. (2015). "The role of humanistic disciplines in a pedagogy of advancedesign" en Advanced Design Cultures: Long-Term Perspective and Continuous Innovation. Springer.

ROA ACOSTA, R. (2006). "Formación de profesores en el paradigma de la Complejidad" en Educación y Educadores, vol. 9, no. 1, p. 149-157.

ROMERO-PÉREZ, C. (2003). "Paradigma de la complejidad, modelos científicos y conocimiento educativo" en Agora digital, 1, p. 1-10.

ROSSI, P. G. (20109. Tecnologia e costruzione di mondi: post-costruttivismo, linguaggi e ambienti di apprendimento. Roma: Armando.

ZONNEVELD, W., WATERHOUT, B. (2005). "Visions on territorial cohesion" en Town Planning Review, vol. 76, no. 1 , p. 15-27.

ZURLO, F. (2003). "Definizione di Capitale Territoriale" en: Castelli, A., Villari, B. STAR | Sistema Topologico Argomentativo della Ricerca | Costruire l'organizzazione della conoscenza | Il caso ME.Design. Milano: Poli.design. 